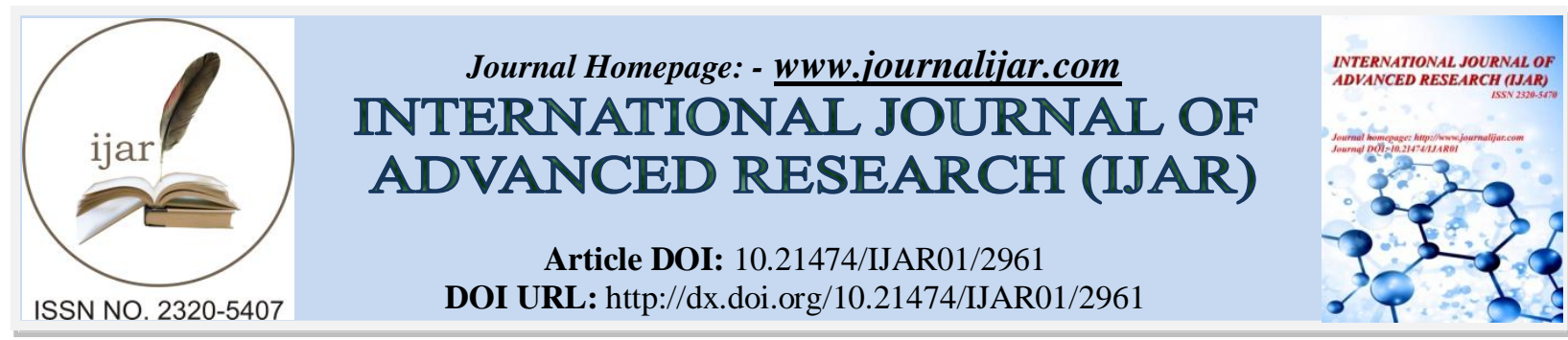

RESEARCH ARTICLE

\title{
COMPUTATIONAL ANALYSIS OF FLAME BEHAVIOR EJECTED FROM UP TO DOWN INSIDE A VERTICAL COMBUSTION CHAMBER OF A BOILER USING IRAQI NATURAL GAS AS A FUEL.
}

\author{
Dr. Ayad Younis Abdulla ${ }^{1}$ and Omar Abdulhadi Mustafa Almohammed ${ }^{2}$. \\ 1. Assistant professor in Northern Technical University, Iraq. \\ 2. Assistant lecturer in Northern Technical University, Iraq.
}

\section{Manuscript Info}

Manuscript History

Received:

Final Accepted:

Published:

\begin{abstract}
Combustion study of Iraqi natural gas used in diffused shape flame is necessary to improve energy conversion in power plants and other usage of thermal systems. Oxidization of fuel to get energy is not a function of chemical reaction speed which happened very fast. This response occurs when there is a mixture contains an amount of air with any selected fuel. This study concentrated on the effect of bouency on flame length since the mixture ejected up to down. Till now, most studies focused on burning fuel in horizontal flame where bouency force effect on its length assumed to be negligible. The result from this study leads to the conclusion that the short flame length that has no effect on the combustion chamber erosion.
\end{abstract}

Copy Right, IJAR, 2016,. All rights reserved.

\section{Introduction:-}

Flame geometry (length and width) can give an indication about radiative heat transfer and fire spread inside a combustion chamber [1]. It is also an important parameter used in burner design as the optimum purpose of a perfect design to extract the maximum amount of energy from the burnt fuel. The shape of flame can clarify the burning process.

Many researchers studied the flame geometry used different approaches [1,2, 3, 4]. Forman [1] and Spalding [2] introduced a mathematical model of the flame. Becker et al [3] presented a correlation about flame dimension while Hamodat et al [4] used high speed camera to formulate the short exposures and put a correlation comparable with that found by Becker.

In the present work, a consistent computer program [5] was used to study the flame length and its behavior inside of a boiler using Iraqi Liquefied petroleum Gas LPG.

\section{Theory:-}

The flame generated as a result of burning fuel flowing outside an orifice hole, nozzle in still air is called free diffusion flame. Two factors strongly affecting the vertical flame behavior: the buoyancy force due to density difference during boiler height and the momentum forces due to fuel and air velocities coming out of the orifice or nozzle and direction guides. 
Most of the researches and results obtained in the last twenty years were for horizontal flames, where the buoyancy forces can be neglected. Hawthorne et al [6] derived the following formula to predict the horizontal flame length ratio. They concluded that it depends on fuel specification and the aero-dynamic properties within the turbulent layers during combustion process.

$$
\frac{l_{\mathrm{f}}}{d_{\mathrm{o}}}=3.1\left[\frac{\lambda_{\mathrm{B}}+1}{1.31}(2 \mathrm{Sc}+1)-1\right] \sqrt{\frac{\rho_{\mathrm{f}}}{\rho_{\mathrm{m}}}}
$$

Where; $l_{\mathrm{f}}$ : flame length, $d_{\mathrm{o}}$ :nozzle or effective orifice diameter, $\lambda_{\mathrm{B}}$ : air-fuel ratio, Sc: Schmidt number $(\mathrm{Sc} \approx 0.8-0.85), \rho \mathrm{f}$ : fuel density at injector outlet, $\rho \mathrm{m}$ : average density of flame layers.

Injector diameter $d_{\mathrm{o}}$ at constant volumetric flow rate of fuel plays a big role on flame length controlling, where injection speed $u_{0}$ will decrease as the diameter of nozzle increase [6].

Becker [3] proposed a dimensionless parameter to govern these forces. Richardson number (1/ Fraud number) which is defined as: buoyancy / input momentum.

$\mathrm{Ri}_{\mathrm{o}}=\mathrm{g} d_{\mathrm{o}} / u_{\mathrm{o}}{ }^{2}$

Where; g: acceleration due to gravity, $d_{0}$ : effective orifice diameter, $u_{0}$ : mean fuel velocity at the orifice outlet.

$$
d_{\mathrm{o}}=d_{\mathrm{i}}\left(\rho_{\mathrm{f}} / \rho_{\mathrm{a}}\right)^{0.5}
$$

Where; $d_{\mathrm{i}}:$ orifice diameter, $\rho_{\mathrm{f}}$ : fuel density at orifice outlet, $\rho_{\mathrm{a}}$ : air density.

For $\mathrm{Ri}_{\mathrm{o}}>1$, the flame will be buoyancy controlled, but if $\mathrm{Ri}_{\mathrm{o}}<1$, the momentum will control the flame. For pure propane fuel, Becker [3] proposed the following formula:

$$
\begin{aligned}
& l_{\mathrm{f}} / d_{\mathrm{o}}=63.4 \mathrm{Ri}_{\mathrm{o}}^{-0.13} \\
& \text { For } 10^{-5}<\mathrm{Ri}_{\mathrm{o}}>0.005 .
\end{aligned}
$$

A mathematical simulation of all processes inside the combustion chamber had been introduced in the current work. The simulation included the gas movement, heat transfer, chemical reactions and burning products. The physical process had been translated into mathematical differential equations which, in turn, had been solved using a consistent computer program [5]. The velocity components, temperature and pressure had been calculated at each node of the proposed mesh.

\section{Combustion chamber description:-}

The combustion chamber under investigation is a cylinder with inner diameter of $(510 \mathrm{~mm})$ with a conical entrance. The burner is fixed at the beginning of the cone. It contains two channels, the first one is of $(140 \mathrm{~mm})$ in diameter which allows the primary air to enter the combustion chamber (10\% of the total air volume). The second channel is an annular with adjustable directional gates which allows the secondary air to enter the system with an annular movement. Figure (1) shows the dimensions of talk about. 


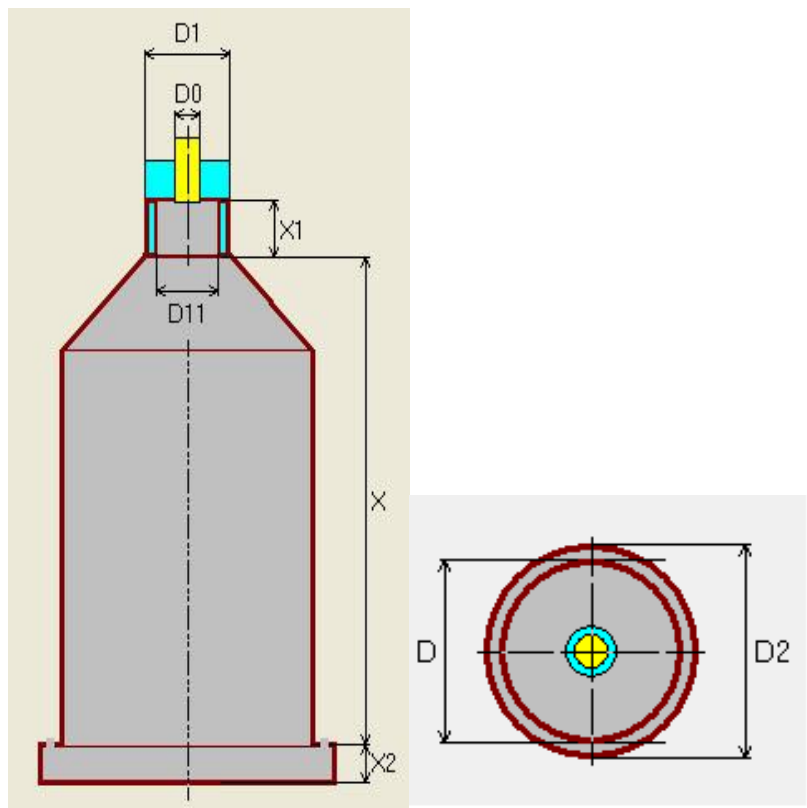

Figure 1:- dimensions of combustion chamber where; D1: diameter of burner(160mm), D0: diameter of jet(variable), D11: diameter of primary air entrance $(140 \mathrm{~mm}), \mathrm{X} 1$ : air channel length $(100 \mathrm{~mm}), \mathrm{X}$ : combustion chamber length $(2200 \mathrm{~mm}), \mathrm{X} 2$ : turning cup length $(80 \mathrm{~mm})$, D: diameter of combustion chamber $(510 \mathrm{~mm}), \mathrm{D} 2$ : diameter of turning cup $(600 \mathrm{~mm})$.

The fuel (natural gas) is ejected through a nozzle of a diameter $(5-26 \mathrm{~mm})$ which is located at the center of the burner. The velocity of the injected gas (fuel) is (340 to $12.6 \mathrm{~m} / \mathrm{sec}$ ) depending on the nozzle diameter and a different ejected fuel volume.

\section{Grid generation description:-}

In order to get an accurate result with the minimum computing time, the combustion chamber had been divided into longitudinal, radial and latitudal grids. The longitudinal direction is divided into 176 elements while the radial direction is divided into 57 cylindrical elements. Another division is a latitudal one. It contains 4 portions.

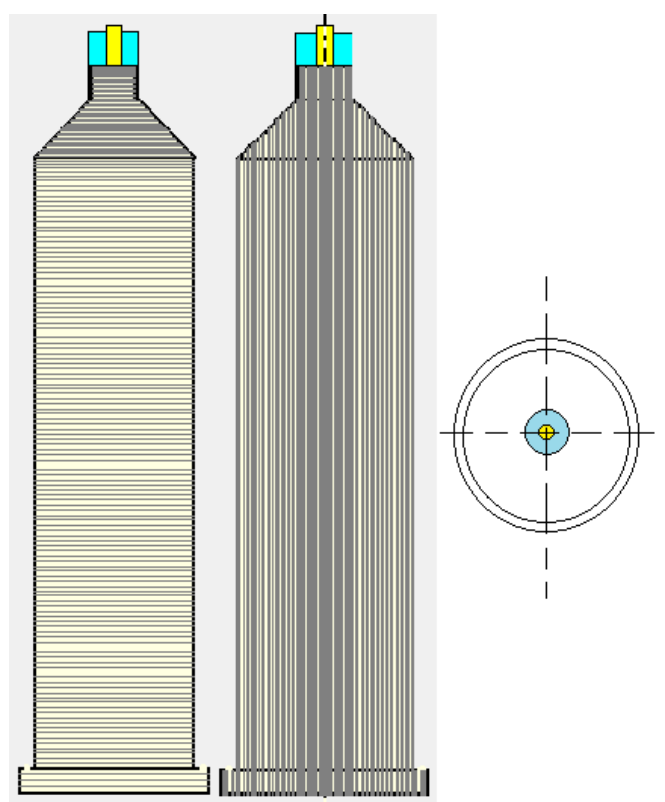

Figure 2:- longitudinal, radial and latitudal grids. 
According to the combustion nature and in order to reduce the computing time, the elements are not equal in size. Figure (2) shows the combustion chamber grid division.

Iraqi natural gas specification.

\begin{tabular}{|c|c|c|c|c|}
\hline $\mathrm{CH}_{4}$ & $\mathrm{C}_{2} \mathrm{H}_{6}$ & $\mathrm{C}_{3} \mathrm{H}_{8}$ & $\mathrm{H}_{2} \mathrm{~S}$ & $\mathrm{~N}_{2}$ \\
\hline $87.5 \%$ & $3 \%$ & $2 \%$ & $2.5 \%$ & $5 \%$ \\
\hline
\end{tabular}

\section{Results:-}

The best way that shows the effect of nozzle diameter changing on flame length is by comparing between different cases through the results of program which gives a graphical shape of flame inside of combustion chamber. All dimensions of flame clearly shown below:

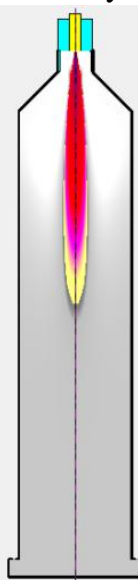

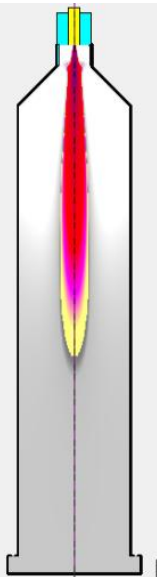

b

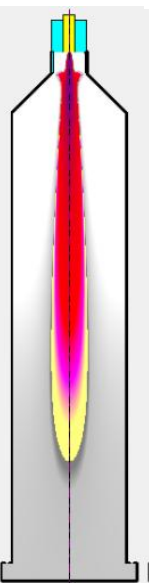

c

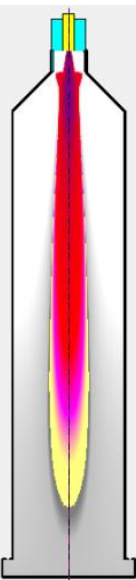

d

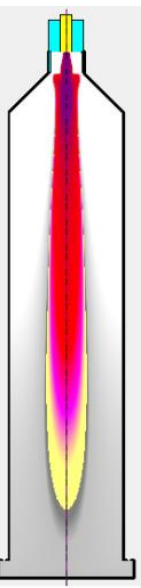

e

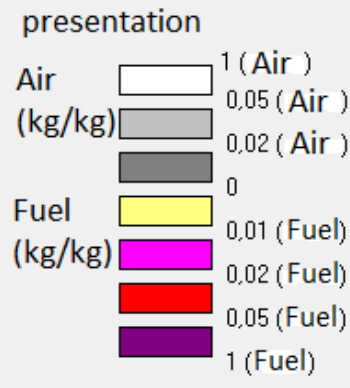

Figure 3:- flame shape inside of combustion chamber, Fuel injector diameter in (a) situation is $6 \mathrm{~mm}, 8 \mathrm{~mm}$ in (b), $12 \mathrm{~mm}$ in (c), $18 \mathrm{~mm}$ in (d) and $22 \mathrm{~mm}$ in (e).

The relationship between flame length and throttle diameter is directly until injection speed of $26.2 \mathrm{~m} / \mathrm{s}$ (curve number 1 and 2) then still constant. But when fuel speed drop to $12.56 \mathrm{~m} / \mathrm{s}$, flame length will decrease (curve number 3). The following curves show flame behavior during variable fuel speed caused by nozzle diameter changing.

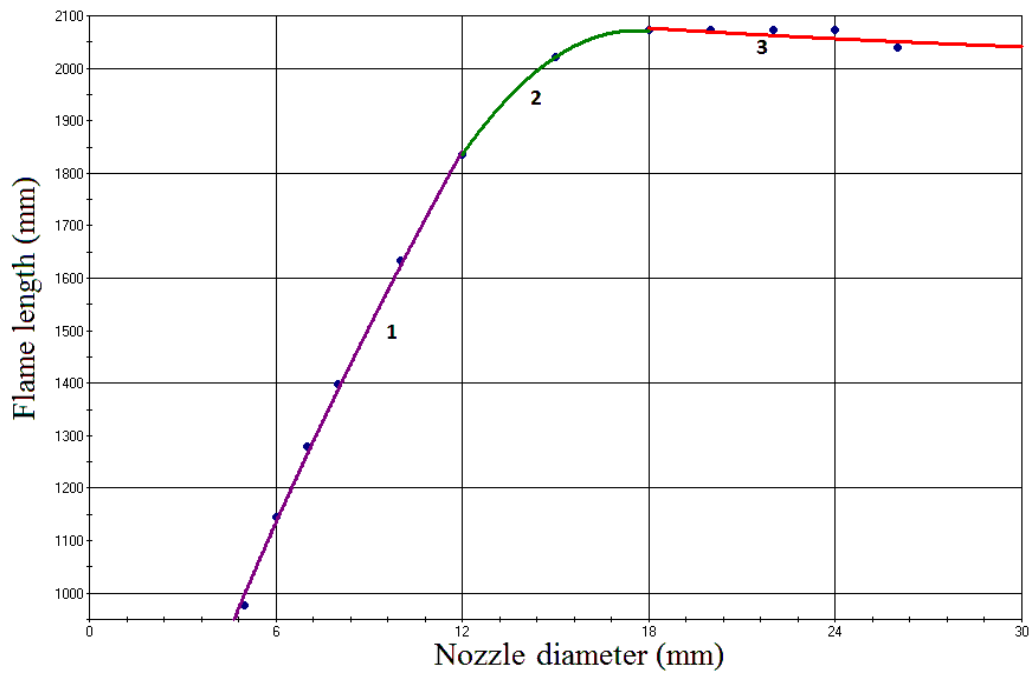

Figure 4:- effect of nozzle diameter changing on flame length

Fraud number content fuel injection speed as one of its parameters. It is an important factor to build dimensionless relationship of flame length divided by throttle diameter in one side and that number in the other side. Fraud number 
can be said is the guide of combustion process that control flame length both in horizontal and vertical case [7]. As shown in figure, the drown curve is divided into two parts. The first (basic) is to low injection speed of fuel. The limitation of this case is $(\mathrm{Fr}<10000)$. It may be represented by the following equation:

$$
l_{f} / d_{\mathrm{o}}=21,9 \mathrm{Fr}^{0,198}
$$

Where: $l_{\mathrm{f}}$ - is flame length, $d_{\mathrm{o}}$ - nozzle diameter. The resultant equation is near to that given in [5] and [8]. The power of Fraud number in [8] is got from experimental work which is equal to 0.2. That mean, the present work gives identification of flame behavior as in real process.

The second (transition) part represented by curve 2. It is for high range of Fraud number ( $\mathrm{Fr}>30000$ ). In its equation, Fraud number has smallest power as shown below:

$$
l_{f} / d_{\mathrm{o}}=79,8 \mathrm{Fr}^{0,0635}
$$

Here creation of entrance from first part in which strong effect of Fraud number to second part where lifting force acting on flame represented by bouency.

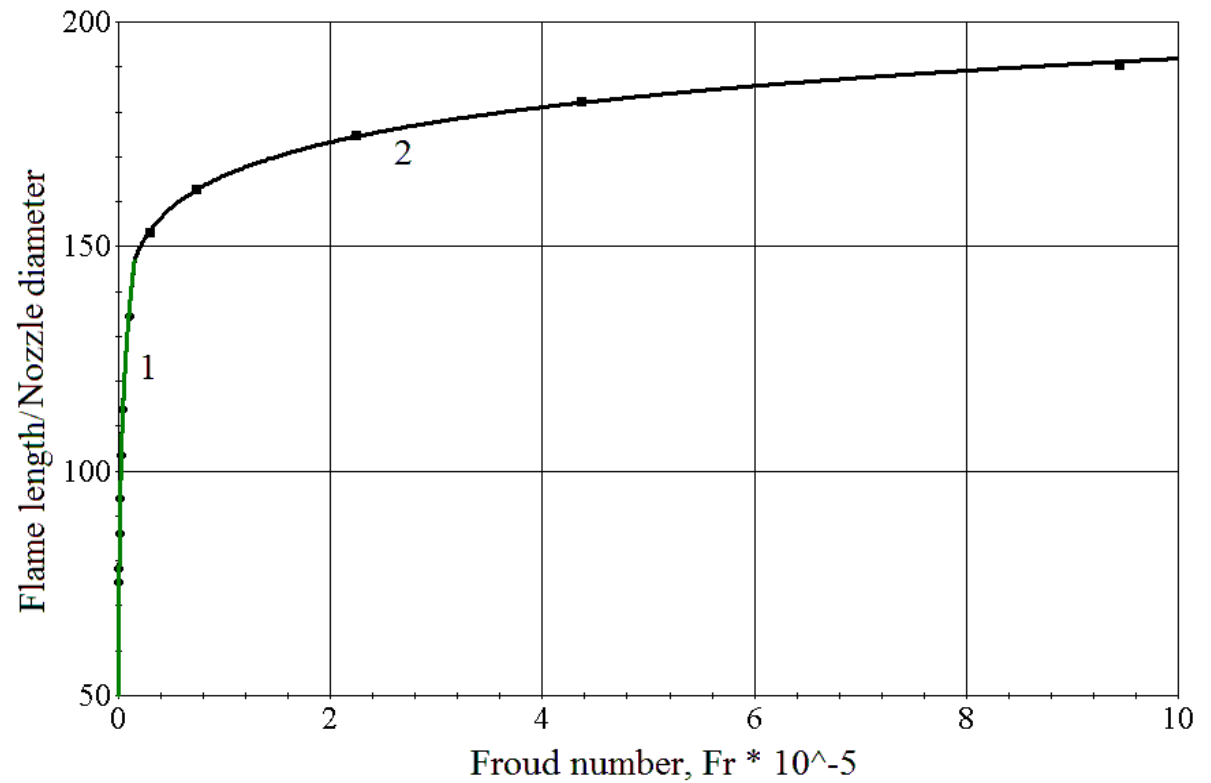

Figure 5:- Dimensionless graph shows effect of Fraud number on flame length divided by diameter of fuel injector.

The effect of pressure in the beginning of combustion chamber on flame also can be studied. In the figure below the difference in color shows the difference in pressure. Blue color mean low pressure (negative) at that location while purple is for positive pressure. Negative pressure resulted from high speed of fuel because the relation between pressure and flowing speed inversely. Pressure in primary air entrance plays big role in burning process because when its magnitude is negative will induce combustion process starting early inside of that canal. All that happened because of sucking force affect on air - fuel mixture in near space. So that; flame length in using of small diameter will be shorter than that in case of large diameter until fuel injection speed decrease to about $26 \mathrm{~m} / \mathrm{s}$, at that time buoyancy force resist flame elongation. 


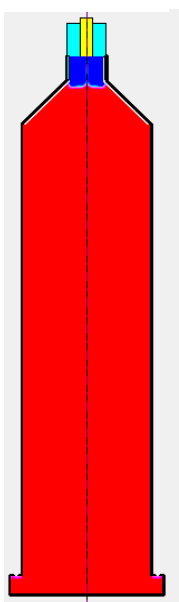

a

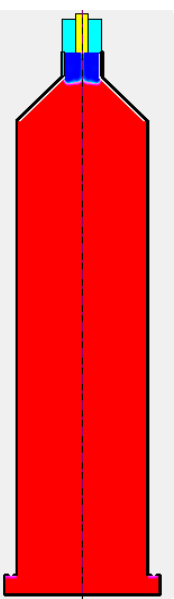

b

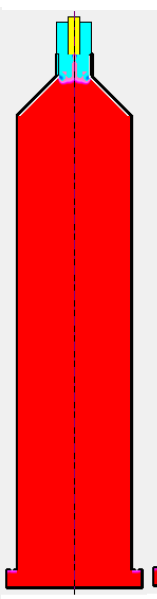

c

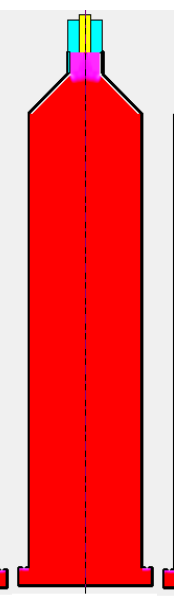

d

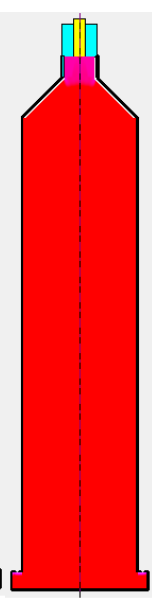

e presentation

pressure, pa.

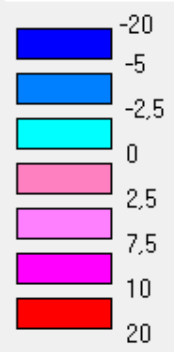

Figure 8:- pressure changing through combustion process. Fuel injector diameter in (a) situation is $6 \mathrm{~mm}, 8 \mathrm{~mm}$ in (b), $12 \mathrm{~mm}$ in (c), $18 \mathrm{~mm}$ in (d) and $22 \mathrm{~mm}$ in (e).

\section{Conclusions:-}

1. Flame length: Three equations can govern the flame length depending on nozzle diameter $\left(d_{0}\right)$ as shown in figure (4).

2. for small nozzle hole diameters $(5-12 \mathrm{~mm}): l_{\mathrm{f}}=323.6\left(d_{0}\right)^{0.7}$

3. for medium nozzle diameters $(12-18 \mathrm{~mm}): l_{\mathrm{f}}=-7.56\left(d_{\mathrm{o}}\right)^{2}+266\left(d_{\mathrm{o}}\right)-268$

4. for large nozzle diameters $(18-26 \mathrm{~mm}): l_{\mathrm{f}}=2291 /\left(d_{\mathrm{o}}\right)^{0.034}$

\section{Discussion:-}

The photos shown in figure (3) show the flame length for different diameters at constant volumetric flow rate (24 $\left.\mathrm{m}^{3} / \mathrm{hr}\right)$ and for fixed combustion chamber length of $(220 \mathrm{~cm})$.

It can be noted that for small hole diameters, the combustion will start at the same moment of fuel impinging as shown in fig.(3-a). The fuel enters the combustion chamber with high activity. In the large diameter hole, there will be a delay in combustion which will increase the flame length, fig. (3-c,d). The reason behind this is the turbulence inside the combustion chamber due to fuel impinging velocity.

Figure (5) shows the relationship between Fraud number (Fr) with $\left(l_{\mathrm{f}} / d_{\mathrm{o}}\right)$. It can be noted that as the fuel injector diameter increase, (Fr) becomes more asymptotic to the vertical axis, while for small diameters; (Fr) increases and become constant steeping along the x-axis. As the injector diameter decreases, it is noted that (Fr) slightly changed.

\section{References:-}

1. Forman, A. Williams, (1995), "Combustion Theory", Benjamin/ Cummings.

2. Spalding, D. Brian, (1979), " Combustion and Mass Transfer", Pergamon Press.

3. Becker, H.A. and Yamazaki, S., (1978), " Momentum Flux and Temperature in Vertical Free Turbulent Diffusion Flames", Combustion and Flames, 33 ,PP 123-194.

4. Hamodat, A. H., Ahmad, B. I., Al-Saffar, A. S., (1992), "Free Diffusion Flame Height", The Third Scientific Conference of Technical Education.

5. Альмохаммед О.А., Кузнецов В.А. Численное исследование закономерностей горения природного газа в вертикальной топке // Вестник БГТУ им. В.Г. Шухова. 2013. № 2. - С. $163-167$.

6. Hawthorne, W. R., Weddel, D. S., Hottell, H. C.,(1949), " Mixing and Combustion in Turbulent Gas Jet", Third Symposium on Combustion and Flames and Explosion Phenomena, PP 266-288.

7. Трубаев П.А., Кузнецов В.А., Беседин П.В. Методы компьютерного моделирования горения и теплообмена во вращающихся печах. - Белгород, Изд-во БГТУ: БИЭИ, 2008. - 230 с.

8. Семикин И.Д., Аверин С.И., Радченко И.И. Топливо и топливное хозяйство металлургических заводов. - М.: Металлургия, 1965. - 392 с. 